\title{
The Function and Value of Film and Television Works in the Teaching Practice of Social Work Courses
}

\author{
Haoyu Wang ${ }^{1, *}$ Yan $\mathrm{CaO}^{2}$ Run Wang ${ }^{3} \mathrm{Xu} \mathrm{Su}^{4}$
}

${ }^{1}$ Beijing No.27 High School, Beijing, China

${ }^{2}$ Beijing University of Civil Engineering and Architecture, Beijing, China

${ }^{3}$ Beijing Institute of Graphic Communication, Beijing, China

${ }^{4}$ Manage School, Beijing Film Academy, Beijing, China

*Corresponding author. Email: bj27wanghaoyu@163.com

\begin{abstract}
Social work specialty belongs to the practical, operational and applied social science. In professional teaching practice, it is required to pay attention to the combination of social work and practice. As an auxiliary means of social work teaching, the film and television works can effectively serve teaching. This paper analyzes the relationship between film and television works and social work professional education, clarifies the role and value of film and television works in social work professional teaching practice, and explores the integration of social work professional teaching practice and film and television works from the perspectives of social work value introduction, helping people to help themselves, crisis psychological intervention and so on.
\end{abstract}

Keywords: Film and television works, Social work, Teaching practice.

\section{INTRODUCTION}

The teaching practice of social work is very important in the educational process of social work. If the professionalization of social work is the basis and premise of the cultivation and development of social work in China, it is believed that education is not only a core link of the whole social work education, but also the core difficulty in the professionalization of existing social work according to social work professional values. The teaching practice of social work curriculum is based on the whole social work values and methodology system. The teaching practice of social work curriculum should also stand the test. The introduction of film and television works in the teaching practice link can improve students' professional and vocational ability and promote the process of localization and professionalization.

\section{FILM AND TELEVISION TEACHING IS AN USEFUL TEACHING METHOD FOR THE TEACHING OF SOCIAL WORK SPECIALTY}

Since the restoration of social work education in Chinese colleges and universities, great progress has been made in terms of the number of colleges and universities, the quality of teachers, the number of students, the construction of teaching materials and the level of training. Chinese construction has been basically completed in social work education. However, it is necessary to be aware that there is still a certain gap compared with the development level of international social work education. Therefore, human beings in China should also focus on the practicality of professional education according to the connotation of social work education, adjust and improve the organic integration of social work theory and professional value and the cultivation of students' personal moral growth. [1] 
The influence of film and television works on social work education is mainly achieved by the means of students finding social problems through watching film and television works, popular science videos and literature books. Then, students can find out the solutions to corresponding problems with the use of the mastered professional theories and skills. In this process of thinking and discussion, students can constantly deepen their professional ideas, build their own professional knowledge system, enrich their professional values and ethics, and promote professional growth in an all-round way. [2]

Social work specialty pays attention to practicality and operability. The traditional classroom form is often used in teaching links, and then the values and ethics of social work can not completely permeate. In this process, film and television teaching is an useful teaching means, which has been proved to be effective through the practice. Film is a comprehensive art that contains literature, drama, photography, painting, music, dance, writing, sculpture, architecture and other arts, but it also has its own artistic characteristics and means of expression that surpasses all other arts, and the film can be copied and shown in large quantities. When film appears in the classroom as a course, it can not only comprehensively improve students' cultural literacy, but also improve teaching efficiency, and promote the cultivation of students' social work values and abilities. [3][4]

\section{THE ROLE OF FILM AND TELEVISION WORKS IN TEACHING PRACTICE OF SOCIAL WORK COURSES}

\subsection{Using Film Clips to Help Students Understand the Learning Content}

The film can be played as a whole, or the clips can be intercepted and played during the teaching process. If it is not a separate course, it is afraid that playing the whole film will take more classroom time. Generally speaking, teachers will ask students to watch it completely after class, and intercept some of the clips that are most useful for professional teaching in class to play. With the explanation of social work teaching methods such as case work and group work, it will be intuitive and perceptual in the whole teaching process. The appearance of image data will make students willing to accept, perceptual to understand deeply. There are many knowledge and skills in the practical education of social work that must be deepened in practice. Film and television appreciation can be immediate in the classroom. For example, in terms of medical social work, it is difficult to find a suitable professional institution for students to visit and practice. The development of the film "Life is a miracle" is carried out in the hospital. The protagonist is a role transformed from an outstation social worker to a medical social worker, which is very helpful to students' understanding of knowledge.

\subsection{Using Film Broadcasting as a Supplement to the Teaching Practice of Social Work Courses}

One of the most important components in the process of social work professionalization is the community in the field of social work. Courses such as community construction, community work methods and even community work theory have been able to cover the scope of community work. For young students, they have no personal experience. It is difficult to experience community work only by learning from textbooks. For example, the two films "Home in Shudefang" and "full moon tonight" describe how community workers give full play to their functions in the streets and lanes, serve national construction and solve problems for the people under the two different community systems of Shanghai and Beijing. History has been passing. Such supplement can only be found from image materials, and such a form can not be achieved by other teaching forms, which is very effective in the actual teaching process.

\subsection{Film and Television Appreciation Can Enhance Students' Professional Identity and Stimulate Students' Learning Enthusiasm}

Purposefully organizing students to watch film and television materials in class can make students immersive. With the use of film and television works as a new teaching form, students can easily accept obscure concepts and learn more knowledge, which is helpful for the mastery of social work major, professional values and working skills. In fact, this is also based on the professional characteristics of social work. [5] 


\section{THE VALUE OF FILM AND TELEVISION WORKS IN TEACHING PRACTICE OF SOCIAL WORK COURSES}

The cultural interpretation value contained in film and television works is an overall value attributes including cognitive attribute and aesthetic attribute. For students majoring in social work, individuals have cognitive function and aesthetic interest in film and television works.

\subsection{Helping Students Explain the Value of Social History}

The connotation of sociology, history and politics contained in film and television works is also a common cultural interpretation value in film and television works. As internal cultural morphological characteristics, these cultural values often exist in the internal structure of film and television works. For example, films such as "Qiu Jin" and "Mona Lisa Smile" contain historical events, political storms and social customs. The overall structure of these films shows the hardships and firm beliefs of Chinese women in their pursuit of women's self-liberation.

\subsection{Helping Students Examine the Value of Religion}

Religion has the "beauty of silence", and the audience's reflection on the religious value in film culture is often difficult to go deep. The examination of religious value can draw lessons from philosophical speculative thinking, critical analysis and interpretation. For example, "moon river" is a film full of revolutionary emotions. A river separates secular and religion. The film explains the connotation of closure and freedom. The students can reflect on morality and reinterpret the gods.

\subsection{Helping Students Recognize the Value of Professional Courses}

Social work major is a subject with strong application. The training goal of its professional education is to make students master the professional knowledge and methods of social work and better solve various problems in social development. The introduction of film and television works into the teaching of professional courses can enable students to better integrate the contents of sociology, psychology and social work courses, so as to establish the context of knowledge relationship, clarify the self-value of social work courses and improve students' practical operation ability.

\section{EXAMPLES OF USING FILM AND TELEVISION WORKS IN TEACHING PRACTICE OF SOCIAL WORK COURSES}

\subsection{Application of Film and Television Works in the Process of "Value Introduction" of Social Work Courses}

"Rogue social worker" is a film introducing social workers in Hong Kong. It is very suitable for new students majoring in social work as an introduction film of professional education, or as an introduction film guiding values. In this film, Lin Baile, the protagonist, graduated from social work specialty and taught in the school. In order to realize the value of his social work, he went to the youth center in community, where he met all kinds of things. After some twists and turns, he finally did the social work he wanted to do, which made him excited. What this film can do for students to pay attention to or for teaching is to highlight several important areas of social work in Hong Kong, such as community social work, youth social work, outreach social work, addiction prevention social work, case social work, etc. Although several scenes are required by feature films, the process is not as deep as that of teaching films. But at least a student who has not been exposed to what social work is and what social work does can understand the major and occupation of social work.

\subsection{Application of Film and Television Works in the Teaching Content of "Helping People to Help Themselves"}

A critic wrote a passage for "The Chorus": it is a film that makes people cry with joy, and it also creates a new concept of French cinema - the sunny emotional film. Without beauty, violence, action, murder or commercial elements, this good film became the "Chicken Soup for the soul" of the French at that year. "The Chorus" is suitable for the teaching practice of social work because of several highlights of the play. First, the film faces a men's boarding school. The headmaster controlled the problem teenagers by cruel and high-pressure means, and corporal punishment was common here. Mr. Matthew was a talented musician, but in the 
French countryside, he didn't have the opportunity to show his talents. Finally, he became a substitute teacher in the school. His arrival changed the school and children. The whole film scene can make students understand how vulnerable groups are treated in this society, how human beings should face these groups in society and how to help them. Second, in this film, Matthew wanted to change the children. In fact, it is a professional process of helping others help themselves. The protagonist made a mistake and broke the gatekeeper's eyes by means of practical jokes. The headmaster advocated to lock up. Matthew advocated that the student should take care of the injured gatekeeper until he recovered completely, so that he could understand that there is a price to pay for doing wrong things, which is several times better than the effect of direct punishment, and directly reflects the value concept of helping others help themselves. Students can easily understand. In addition, Matthew was very good at discovering the students' strengths, encouraged them to sing, made them do their best, formed a choir, and made these so-called problem students a famous Children's Choir in France. The methods and ideas of group work are vividly reflected in the whole process. [6]

\subsection{Application of Film and Television Works in "Crisis Psychological Intervention"}

The teaching practice of social work course is an essential link in the whole professional course education. With the expansion of psychological counseling from psychiatry to general psychology and intervention in the life of ordinary people, the psychological films have also gone beyond the narrow scope of psychological diseases and criminal psychology, and increasingly select the life phenomenon of ordinary people. "Fearless", filmed in 1993, shows human beings a new field of psychology - crisis psychological intervention. From the perspective of teaching practice, the highlights of the film are as follows. After the emergence of a psychologist who specializes in "crisis intervention", it focuses on some crisis intervention procedures, such as collective psychological counseling and the scene of professional group work, which is a very good model of psychology and group work methods. In the film, it can be seen that the psychologist is a secondary role. His role is to constantly explain to the audience through professional terms that the protagonist's current psychological state is not normal and how to return to the normal, which can make the students understand the status of a social worker in the process of group work or the role as a consultant facing the service object, etc.

\section{CONCLUSION}

The introduction of social work professional education in film and television works has brought more possibilities in terms of course design and operation practice. It can meet the teaching objectives of social work, low input cost, and high benefit, which is in line with the actual needs of professionals. It can be said that the setting of film and television text course is successful and feasible, but it also has its shortcomings. Not all professional courses are suitable for the introduction of film and television works. When there are methods such as teaching, discussion and simulation, the proportion of film and television materials in teaching practice should be controlled at $20 \%$ or above. Of course, the experience of combining film and television works with social work education still needs to be explored and accumulated by colleges and universities. There are still many fields to be explored and developed in the future.

\section{AUTHORS' CONTRIBUTIONS}

Haoyu Wang wrote the manuscript, contributed to revising and editing; Yan Cao wrote the manuscript; Run Wang wrote the manuscript; $\mathrm{Xu}$ Su wrote the manuscript.

\section{REFERENCES}

[1] Yang Zhisheng, Yan Fengming. The Effect of Video Materials in the Education of Social Working Practical Teaching [J]. Journal of Jiangsu Vocational and Technical Institute of Economics and Commerce, 2009, 3. (in Chinese)

[2] Haoyu Wang, The Integration of Media literacy education into Ideology and morality education at China's High Schools, Proceedings of the 2nd International Conference on Contemporary Education, Social Sciences and Humanities (ICCESSH 2017), 2017, 191-197.

[3] Haoyu Wang,Tianlong Zhong, Analysis on the Research Hotspots and Trends of the Media Literacy Education for Chinese Students, Proceedings of the 2nd International Conference on Contemporary Education, 
Social Sciences and Ecological Studies (CESSES 2019), 2019, 146-150.

[4] Haoyu Wang, Yong Liu, Zifeng Han, Jianzhang Wu, Extension of media literacy from the perspective of artificial intelligence and implementation strategies of artificial intelligence courses in junior high schools,2020 International Conference on Artificial Intelligence and Education (ICAIE), 2020, 63-66.

[5] Wang Haoyu, Liu Yong. Playing with the media: youth media literacy education $[\mathrm{M}]$, Changchun: Jilin Wenshi Publishing House, 2018. (in Chinese)

[6] Wang Haoyu. Analysis of Psychological Effects in Film Works [M], Beijing: Guangming Daily Publishing House, 2016. (in Chinese) 